College of Veterinary Medicine and Animal Production,

Sudan University of Science and Technology, Khartoum, Sudan.

\title{
HISTOLOGICAL, ULTRASTRUCTURAL AND HISTOCHEMICAL STUDY ON THE POSTNATAL DEVELOPMENT OF PROXIMAL AND DISTAL PORTIONS OF THE SMALL INTESTINE IN MALE RABBITS (ORYCTOLAGUS CUNCULUS)
}

(With 2 Tables and 11 Figures)

\author{
By \\ TAHANY M.M.A. ELNAGY and D.I. OSMAN* \\ * Dep.t of Anatomy, Fac. of Vet. Med., University of Khartoum, Sudan.
}

(Received at 12/9/2009)

\section{SUMMARY}

Histilogical, ultrastructural and histochemical studies were conducted on the small intestine of 50 Blanc de Bouscat male rabbits; the age varied between 0-30 days. The result showed that the progress in age has a pronounced effect on the shape and length of the intestinal villi of the small intestine. The mucosa of the small intestine was lined by simple striated columnar epithelium with prominent goblet cells. The crypts opened adjacent to the bases of the villi as simple, branched, tubular invaginations. The mucosa of the small intestine was covered by columnar cells that contained apical microvilli, oval nucleus, dilated cisternae of rough endoplasmic reticulum, Golgi apparatus, vacuoles and electron dense material in all age groups. The crypts showed some epithelial cells with dilated intercellular spaces and contained apical microvilli, mitochondria, granules with electron dense material, rough endoplasmic reticulum and elongated nucleus. There were a few cells with spherical secretory granules of different size above the nucleus and other cells of polymorphic secretory granules of different sizes beneath and lateral to the nucleus. Positive reaction to PAS diastase resistant material and diastase-digested material (glycogen) was clearly seen in the surface and crypts epithelial cells of different ages.

Key words: Histology, histochemistry, rabbits, intestine. 


\section{INTRODUCTION}

Rabbits are used in a wide range of commercial purposes such as meat in France, Spain, Italy and some Middle East contries, mainly Egypt, hair in production of coats and regal dresses is established in U.S.A.in addition to laboratory uses in medical researches (Yousif and Abdelaziz, 1995).

In Sudan, rabbits are used as laboratory animals and for entertainment (personal observation).

The histology, ultrastructure and histochemistry of the small intestine have been investigated in several birds including chicken (Aticken, 1958; Anderw, 1982), fowl (Micheal, Hodges, 1973; Humphery, Turk; Larson,Sundler, Hakanson, Rehafeld and Stadil, 1974; El-Shamy,1996), balady fowl (Abdel-Shamy, 1996), fayoumi fowl (Salem,1985), white leghorn (Yamauchi and Isshiki, 1991), Turkey (Zoghby, 2000) and quail (Ahmed, 2002).

In mammals the gastrointestinal tract was studied in man (Carleson, 1981), echidna (Krause, 1972; Bayer, 1975) and calf (Staley, Corley, Bush and Jones, 1972), opossum (Krause, cutts and Lesson, 1977) and in camel (Abdel-Magied and Taha, 1995).

In the rabbit, the histology and ultrastructure of the postnatal development of the gastrointestinal tract have only been briefly tackled by Abdel- Magied and Taha (1995) and YuB (1997). From the above mentioned references, it appears clearly that most of the studies were carried out in birds; however mammals have received little attention.

It is therefore decided that the postnatal development of gastrointestinal tract should be thoroughly investigated using the rabbit as an experimental animal. In the present study, only histology, ultrastructure and histochemistry of the small intestine will be delt with.

\section{MATERIALS and METHODS}

The breed which was used in this study was Blanc de Bouscat for meat production. It came from France; it is well known and originated by crosses of Flemish Giant, Argente and Angora. It is a large rabbit with minimum weight for adult bucks of $5,0 \mathrm{~kg}$ and for adult does 5,5 $\mathrm{kg}$. Albinos from crosses were selected and the breed is preferred to commercial meat production for its good carcass quality and produced in large numbers per does and at economic rate. The gestation period of rabbit is remarkable short, ranging between 28- 35 days. Litters are 
usually weaned between 21-26 days old (Sandford, 1996). Mothers were grown and the inbreeding was occurred by natural mating. The newborns were examined quietly; the dead and anomalous ones was removed and we made sure that the stomach was filled with milk, which appeared as white strip under the skin of the abdomen. Litters caring is important to avoid loses and to give normal growth. The litters began feeding at 18 days old and were weaned at 24 days old; the nests were in $37^{\circ} \mathrm{C}$ and with normal day light. The diet/ dry matter physical compositions at ton were yellow corn $30,15 \%$, soybean meal 16, $00 \%$, hay $40,00 \%$, wheat bran $10,35 \%$, ground limestone $2,00 \%$, dicalcium phosphate $1,00 \%$, minerals mixture $0,10 \%$, premix (vitamins for broiler) $0,10 \%$, sodium chloride (common salt) $0,30 \%$ and anti coccidia $0,05 \%$. The diet was common for neonates before and after weaning.

\section{Histology}

The small intestine of all groups in this study was dissected and divided into duodenum, proximal portion (after the duodenum) and distal portion (before the caecum).

Small pieces of tissue, about $1 \mathrm{~cm}^{3}$ in size, were excised from the proximal and distal portion of the small intestine from 32 animals divided into six groups and their ages were 0-day of birth (3 to 5 hours old), 6 days old, 12 days old (suckling neonates), 18 days old, 24 days old (suckling and feeding neonates), and 30 days old (after weaning in 24 days). Each group contained 5 or 6 animals. The tissues were fixed by immersion in different types of fixatives including Bouin's fluid, $10 \%$ formalin and $10 \%$ formal saline. The tissues were processed routinely and stained with heamatoxyline and eosin (H\&E) (Culling, 1973).

Histometrical measurements were carried out in the two segments to determine the length and width of the intestinal villi. Olympus microscope (kc-267145-Tokyo), with ocular micrometer lens X6 was used. The objective lens X10 was used for determining the measurements, after calibrating the ocular scale of the microscope (Thienpont, Rochette and Vamparijs, 1986). Nine measurements were recorded from each group and the average was calculated.

\section{Ultrastructure}

Additional pieces of tissue for ultrastructural studies were taken from 18 animals of different ages. Small pieces of tissue $(1 \times 1 \mathrm{~mm}$ in diameter) were taken immediately after the animal was anesthetized and fixed rapidly in 5\% gluatraldehyde in phosphate buffer (PH 7. 4) for 2- 4 
hours at $4{ }^{\circ} \mathrm{C}$. The tissues were postfixed in $1 \%$ osmic acid for 2 hours, and then processed routinely for transmission electron microscope.

Semithin sections $(0.5 \mu)$ were stained with toluidine blue and examined with the light microscope. The desired regions for electron microscopy were then selected and ultrathin sections were cut and treated with $2 \%$ uranyl acetate and lead citrate for 15 minutes. They were then washed, dried and examined in a Zeiss EM 109 electron microscope (Bancroft and Stevens, 1996).

\section{Histochemistry}

Material for histochemical investigation was obtained from the suckling neonates (6days), the feeding and suckling neonates (18days) and after weaning (30 days) as quickly as possible after anesthesia. Pieces of tissue were taken from the the proximal and distal portions of the small intestine and fixed.

\section{Carbohydrates}

Neutral mucopolysaccharide was investigated in tissues fixed in Bouin`s fluid and Gender`s fluid at $4^{\circ} \mathrm{C}$, processed for paraffin sections and stained with Periodic Acid-Schiff (PAS) technique (Culling, 1973). The presence of glycogen was also investigated by the PAS technique. Control sections for glycogen were treated either with saliva or $0.1 \%$ malt diastase.

\section{RESULTS}

\section{Light Microscopy}

\section{The Proximal Small Intestine}

At 0-day of birth, the mucosa was composed of short irregularly shaped villi lined by striated simple columnar epithelial cells. The nucleus was oval in shape and basally situated. Many mitotic figures were observed. The crypts opened adjacent to the bases of the villi as simple, branched, tubular invaginations with aggregated epithelial cells. Loose connective tissue from the lamina propria extended to the villus core. The lamina muscularis mucosa was arranged in a circular layer and the submucosa was a thin layer of connective tissue. At 6 days old, the mucosa consisted of long cylindrical villi with a few scattered goblet cells and the muscularis mucosa was arranged in a circular layer. Strands of smooth muscle fibers and connective tissue extended between the crypts into the villar cores. The submucosa was a thin layer of loose connective tissue (Fig.1). At 12 days old, the epithelial cells contained basal elongated nuclei and apical vacuolated cytoplasm; the columnar 
cells were short at the base of the villi (Fig.2). Mitotic figures were found in the epithelial columnar cells which covered the whole surface of the villi. At the age of 18 days, suckling and feeding neonates, the mucosa was composed of long and short cylindrical villi lined by striated simple columnar cells with oval basally situated nuclei. Phagosomes were noticed in some columnar epithelial cells and in the villar cores and lymphatic vessels were observed inside some villi.

At 24 days old, the mucosa consisted of long cylindrical villi with permanent secondary folds. At 30 days old, weaned neonates, the mucosa was composed of short club-shaped villi. Several phagosomes were seen in the epithelial columnar cells and in the lamina propria. Many mitotic figures were noticed in the epithelial columnar cells. The other layers (lamina propria, lamina muscularis mucosa and submucosa) were similar in structure to those of 0-day of birth.

\section{The Distal Small Intestine}

In suckling neonates at 0-day of birth, the mucosa was composed of long and short villi lined by simple or pseudostratified striated columnar epithelial cells with oval, basally situated nuclei and apical vacuolated cytoplasm. A large number of mitotic figures were seen. The presence of goblet cells was a prominent feature. The intestinal crypts were in the form of simple, branched, tubular invaginations with many mitotic figures in their epithelium (Fig.3). The muscularis mucosa was poorly developed and consisted of smooth muscle fibers, which were arranged in a circular layer. At the age of 6 days, the mucosa was composed of cylindrical villi and the epithelial cells had a large apical vacuolated cytoplasm. The lamina propria was followed by a layer of muscularis mucosa of circular smooth muscle fibers. Strands of smooth muscle fibers and connective tissue extended into the villar core and around the crypts. At 12 days old, the mucosa contained large cylindrical villi and the epithelial cells with small vacuoles in the cytoplasm and dilated intercellular spaces. Strands of smooth muscle fibers and connective tissue interdigitated between the intestinal crypts and the submucosa consisted of loose connective tissue rich in blood vessels (Fig.4). At the age of 18 days, suckling and feeding neonates. The branching of the intestinal crypts was more developed. Strands of smooth muscle fibres and connective tissue interdigitated between the crypts and inside the villar cores which also contained blood and lymphatic vessels. At 24 days old, the villi were covered by simple striated columnar epithelial cells with homogenous and heterogeneous acidophilic material in the cytoplasm specially around the nuclei (Fig.5). 
At the age of 30 days, weaned neonates, a few of epithelial cells contained apical vacuolated cytoplasm while other cells contained phagosomes in their cytoplasm. The other layers (lamina propria, lamina muscularis mucosa and submucosa) and structures were similar to those of younger groups.

\section{Histometrical Measurements \\ The Proximal Small Intestine}

The average of villi length increased with advancing age and decreased at 18 days old and this may be due to the feeding change and increased at 24 days old and decreased at 30 days old and this may be due to the weaning effect. While the width at the upper, mid and lower parts of the villi increased with advancing age but decreased at 30 days old, this may be due the weaning effect (See Table 1).

\section{The Distal Small Intestine}

The average of the villi length increased with the advancing age but at 6 days old, it decreased and this may be due to the proliferation of the cells and also decreased at 30 days old and this may be due to the weaning effect. While the width of the upper, mid and lower parts increased with the advancing age but decreased at 6 days old and this may be due to the cells proliferation and also decreased at 18 days old due to the feeding change (Table 2.).

Table 1: Showing the measurements of the length and width of the villi of the proximal small intestine.

\begin{tabular}{|c|c|c|c|c|c|c|}
\hline \multirow{2}{*}{$\begin{array}{c}\text { Age in } \\
\text { days }\end{array}$} & \multicolumn{3}{|c|}{ Length $(\mu \mathrm{m})$} & \multicolumn{3}{c|}{ Width $(\mu \mathrm{m})$} \\
\cline { 2 - 7 } & Min & Max & Aver & Upper & Mid & Lower \\
\hline 0 & 92.55 & 140.37 & 116.46 & 12.36 & 17.82 & 15.40 \\
\hline 6 & 131.11 & 148.08 & 139.60 & 12.45 & 19.62 & 16.75 \\
\hline 12 & 166.59 & 240.63 & 203.61 & 13.89 & 21.59 & 14.25 \\
\hline 18 & 64.79 & 114.15 & 89.47 & 14.43 & 21.59 & 26.61 \\
\hline 24 & 89.47 & 129.57 & 109.52 & 31.63 & 40.77 & 43.27 \\
\hline 30 & 101.81 & 112.60 & 107.21 & 22.89 & 26.32 & 26.16 \\
\hline
\end{tabular}


Table 2: Showing the measurements of the length and width of the villi of the distal small intestine.

\begin{tabular}{|c|c|c|c|c|c|c|}
\hline \multirow{2}{*}{$\begin{array}{c}\text { Age in } \\
\text { days }\end{array}$} & \multicolumn{3}{|c|}{ Length $(\mu \mathrm{m})$} & \multicolumn{3}{c|}{ Width $(\mu \mathrm{m})$} \\
\cline { 2 - 7 } & Min & Max & Aver & Upper & Mid & Lower \\
\hline 0 & 89.43 & 122.60 & 101.04 & 12.0 & 14.25 & 11.64 \\
\hline 6 & 67.87 & 75.58 & 71.73 & 11.37 & 12.01 & 11.02 \\
\hline 12 & 92.55 & 115.69 & 104.12 & 16.58 & 16.58 & 19.32 \\
\hline 18 & 86.36 & 157.34 & 121.86 & 12.45 & 17.82 & 16.66 \\
\hline 24 & 115.69 & 200.53 & 158.11 & 15.86 & 17.82 & 19.32 \\
\hline 30 & 66.33 & 118.53 & 92.55 & 18.36 & 26.07 & 24.01 \\
\hline
\end{tabular}

\section{Electron Microscopy}

\section{The Proximal Small Intestine}

At 0-day of birth, the surface epithelium of the proximal small intestine possessed apical microvilli, mitochondria, rough endoplasmic reticulum, free ribosomes, and granules with fine, clear homogenous microparticles and there were also granules of varying size and of low electron density. The nucleus contained heterochromatin. At 6 days old, dilated cisternae of rough endoplasmic reticulum, and vacoules were seen in the columnar cells of the surface epithelium.

Goblet cells contained fine, clear microparticles of premucin droplets and a few droplets with dark core; these droplets occupied the bulk of the cytoplasm and displaced other cytoplasmic components peripherally and basally. At 12 days old, the columnar cells contained irregular vacuoles of different size, Golgi apparatus and oval basally situated nuclei with prominent nucleoli. The junctions between the columnar cells consisted of tight junctions, intermediate junctions and desmosomes. The glandular epithelium showed cells with apical microvilli, mitochondria, oval nucleus and cells in different stages of mitosis (Fig.6). At 18 days old, suckling and feeding neonates, the columnar cells contained vacuoles, homogenous granules and basal nucleus. Irregularly- shaped cells, which contained large nucleus with heterochromatin at the centre and euchromatin at the periphery, and large intercellular space, were seen in the intestinal glands. Accumulated 
mucin droplets were noticed in the goblet cells. At 24 days old, the surface columnar epithelium contained small vacuoles; the columnar epithelial cells of the crypts were irregular in shape with large nuclei and many mitochondria. A few pyramidal (Paneth) cells with clear cytoplasm that contained apical round secretory granules with fine dense microparticles, diffused mitochondria and rough endoplasmic reticulum peripherally to the oval basally situated nucleus were observed (Fig.7). At the age of 30 days, weaned neonates, the surface columnar epithelial cells contained phagosomes (Fig.8). The junctions were clearly seen between the surface columnar cells.

\section{The Distal Small Intestine}

At 0-day of birth, suckling neonates, the surface epithelium composed both columnar and goblet cells. The columnar cells exhibited microvilli, numerous vacuoles, dilated cisternae of rough endoplasmic reticulum, mitochondria, and oval basal nucleus with prominent nucleolus. Tight and intermediate junctions, desmosomes, and lateral membranous interdigitaions joined the columnar cells together. The goblet cells consisted of round mucigenous granules. The intestinal crypts were lined with columnar cells with apical microvilli, dilated cisternae of rough endoplasmic reticulum and mitochondria. Cells containing rough endoplasmic reticulum, mitochondria, a nucleus and basally situated polymorphic secretory granules were scattered in between the cells that lined the crypts. At 6 days old, the surface columnar epithelial cells exhibited microvilli, dilated cisternae of rough endoplasmic reticulum, oval and basal nucleus and lateral membranous interdigitation were noticed. Goblet cells opened to the lumen in between the epithelial cells (Fig.9). At 12 days old, the columnar cells contained free ribosomes, low electron dense material, phagosomes, mitochondria, and basal nuclei. At 18 days old, suckling and feeding neonates, goblet cells showed premucin droplets apically and the nuclei basally. At 24 days old, numerous mitochondria, elongated and basally situated nuclei with large amount of hetrochromatin were seen in the columnar cells. The columnar cells rested on a highly folded basal lamina. The junctions between the columnar cells consisted of tight and intermediate juctions and desmosomes. Large intercellular spaces were seen between the columnar cells. Goblet cells were seen with round shape nucleus and premucin droplets filled the cytoplasm. The columnar cells of the crypts possessed large number of mitochondria, prominent intercellular spaces and lateral membranous interdigitations. Cells with 
pyramidal shape and clear cytoplasm were observed. These cells contained mitochondria, rough endoplasmic reticulum, elongated nucleus and polymorphic secretory granules, which were basally situated (Fig.10).

\section{Histochemistry}

\section{The Proximal Small Intestine}

At six days old, the epithelium of the intestinal villi and the crypts of Lieberkuhn reacted positively with PAS stain. The reaction was markedly demonstrated in the cytoplasm of the goblet cells and the striated border of the epithelial cells. The cytoplasm of the surface and the crypts of Lieberkuhn epithelium possessed many fine glycogen particles (PAS-positive diastase digested granules). At 18 days old, goblet cells and the striated border of the surface epithelium showed positive reaction to PAS and the striated border of the intestinal glands epithelium showed weak reaction to PAS. The cytoplasm of the surface epithelium and cells of the intestinal glands showed the presence of many fine glycogen particles and numerous phagosomes (Fig.11, a, b.). At 30 days old, goblet cells and the striated border of the surface and the intestinal glands epithelial cells gave positive reaction with PAS technique and their cytoplasm showed many fine glycogen particles and a few phagosomes.

\section{The Distal Small Intestine}

At six days old, the epithelium of the intestinal villi showed strong reaction to PAS stain, and numerous fine glycogen particles were observed. At 18 days old, goblet cells and the striated border of the epithelial cells revealed positive reaction to PAS technique and a few fine glycogen particles were found. At 30 days old, goblet cells and the striated border of the epithelial cells showed positive reaction with PAS stain and the cytoplasm contained many fine glycogen particles and a few phagosomes. 


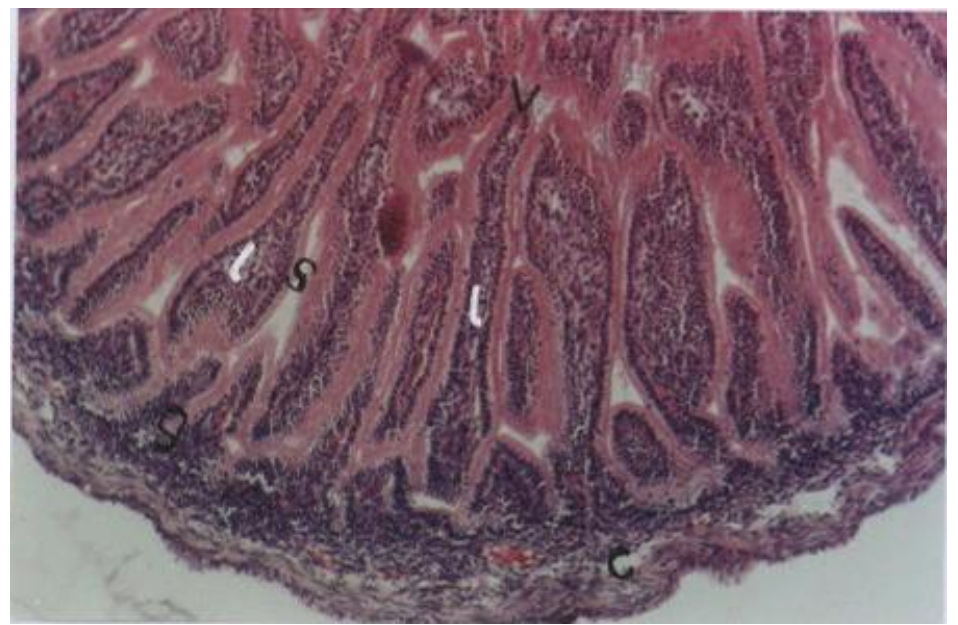

Fig.1. A photograph of proximal intestinal mucosa at 6 days old, showing villi (v), columnar cell ( $\mathrm{s}$ ), intestinal gland (g), lamina properia (l), and submucosa (c). H\&E, X 10.

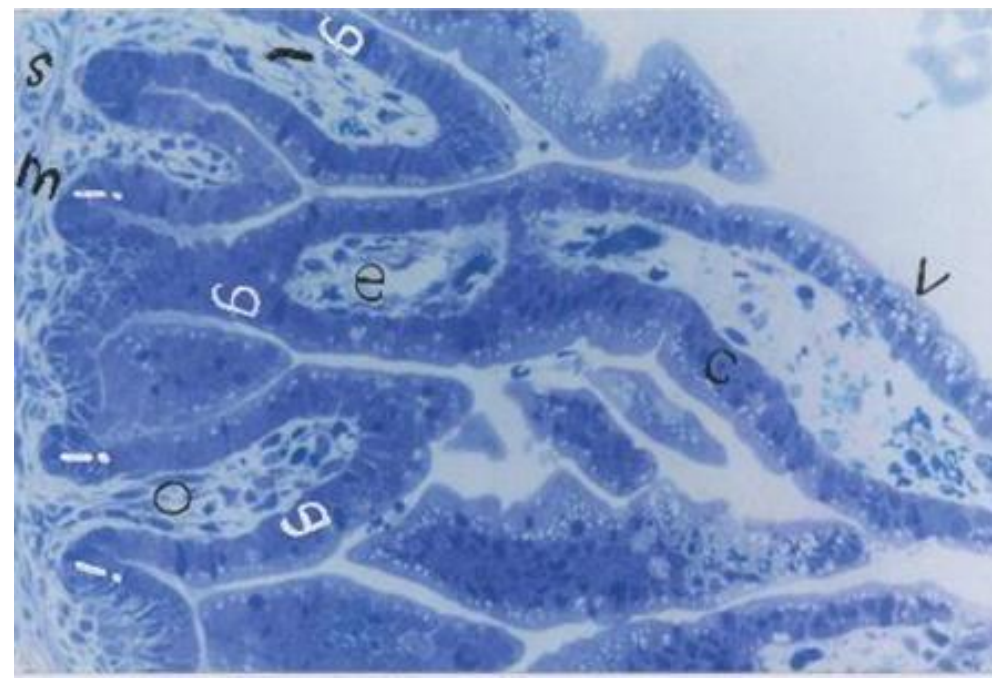

Fig. 2: A photograph of proximal small intestine at 12 days old, showing villi (v), columnar cells with vacoules (c), goblet cells (g), lamina properia (l), fibroblasts (o), vessel (e), intestinal glands (i), muscularis mucosae (m) and submucosa (s). Tolouidine blue, X25. 


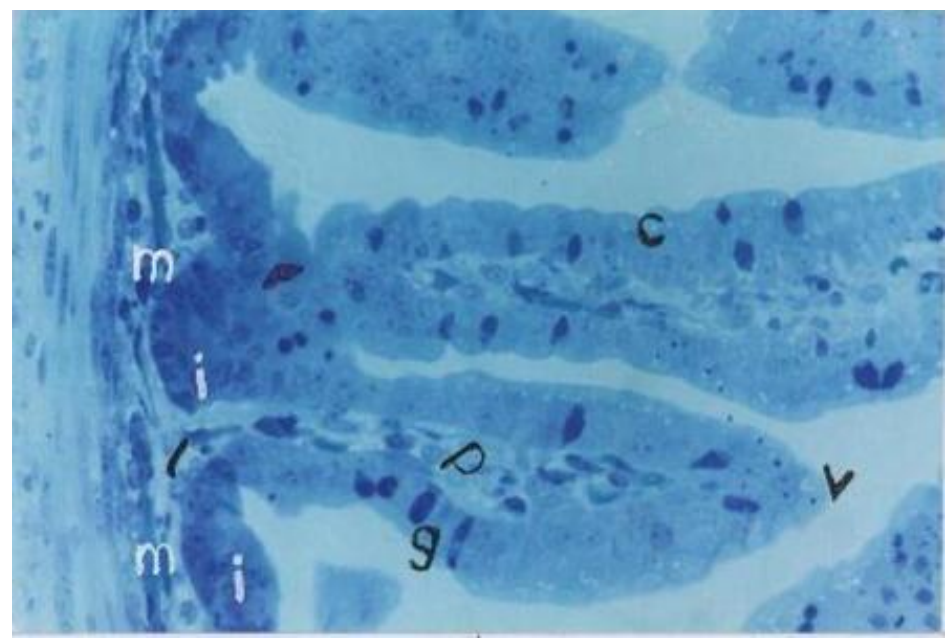

Fig. 3: A photograph of distal small intestine mucosa at 0- day of birth. Note the presence of villi (v), columnar cells (C), goblet cells (g), intestinal crypts (i) lamina propria (l) and muscuilaris mucosa (m).Tolouidine blue, X 40.

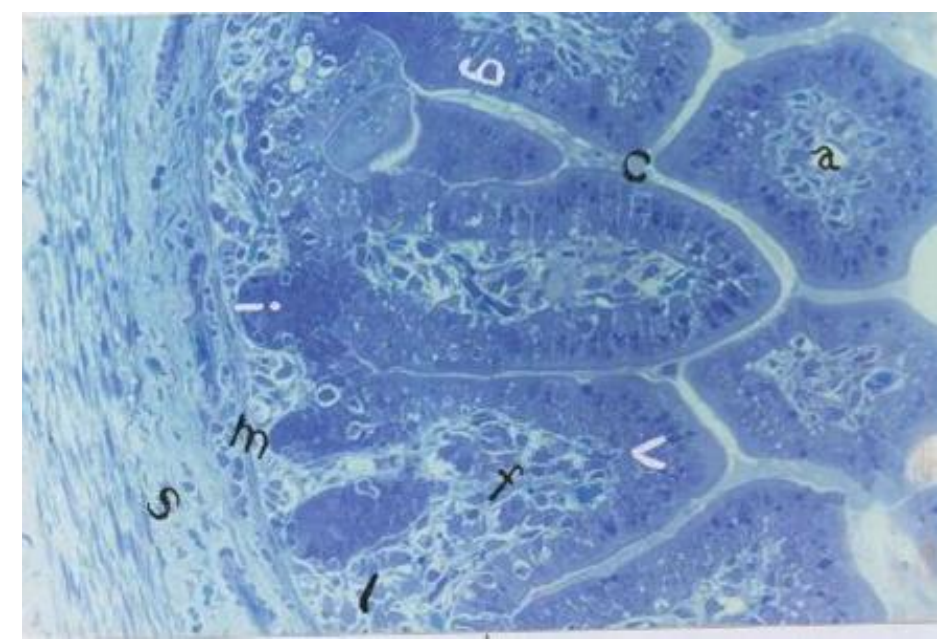

Fig. 4: A photograph of distal small intestine at 12 days old, showing villi (v), columnar cells (c), goblet cells (g), intestinal crypts (i). Lamina propria (l), fibroblasts (f), muscularis mucosae (m) and submucosa (s). Note the presence of a lacteal in cross section (a) Tolouidine blue, X 25 . 


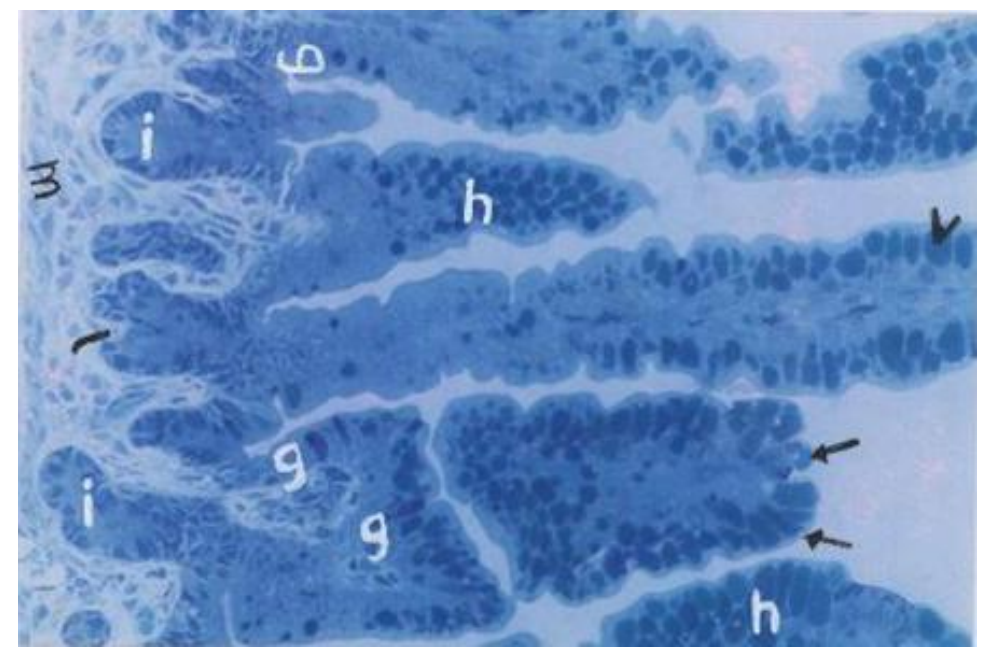

Fig. 5: A photograph of distal small intestine at 24 days old, showing villi (v), columnar cells (arrows), goblet cells (g), granules with homogenous material (h), intestinal crypts (i), lamina propria (l), and muscularis mucosae (m). Toloiudine blue, X 25.

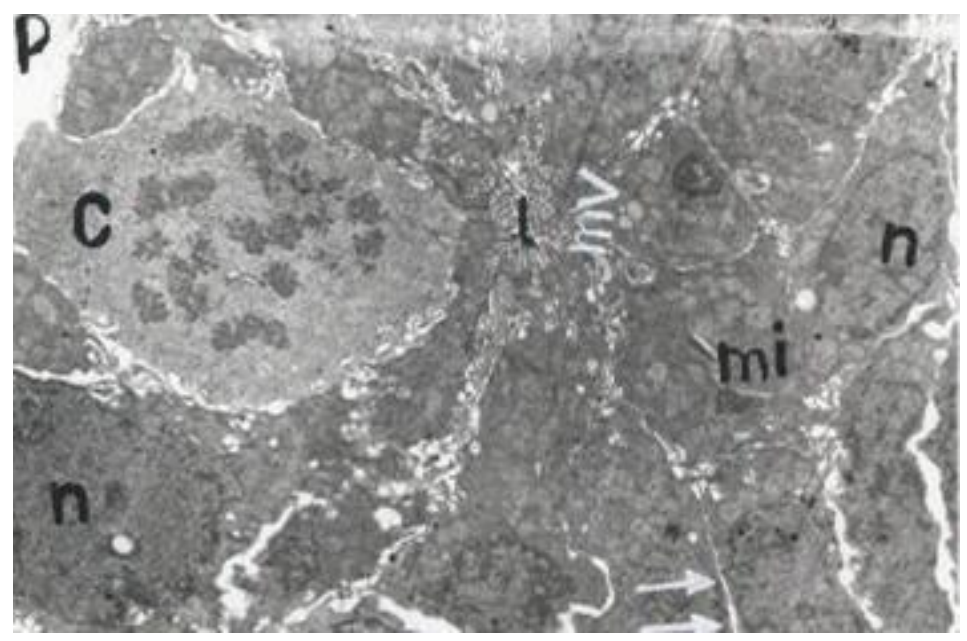

Fig. 6: A micrograph of the proximal small intestine at 12 days old. The intestinal gland showing cells with microvilli (mv), at the lumen (1), nucleus (n), mitochondria (mi) and intercellular spaces (arrows). (c) Cell in prophasethe with chromosomes had condensed and the nuclear membrane had disappeared. Lamina propria (p). Uranyl acetate and lead citrate, X 2.700. 


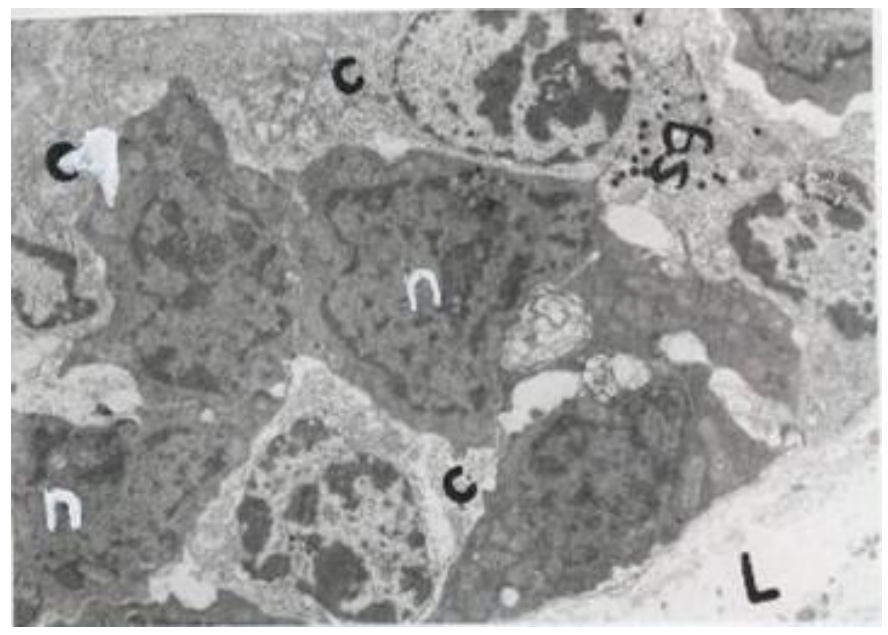

Fig. 7: A micrograph of the proximal small intestine at 24 days old, showing crypt epithelial cells with nuclei (n) and cell with secretary granules (sg). Note the cells with pale cytoplasm (c) and lamina properia (L). Uranyl acetate and lead citrate, X 4000.

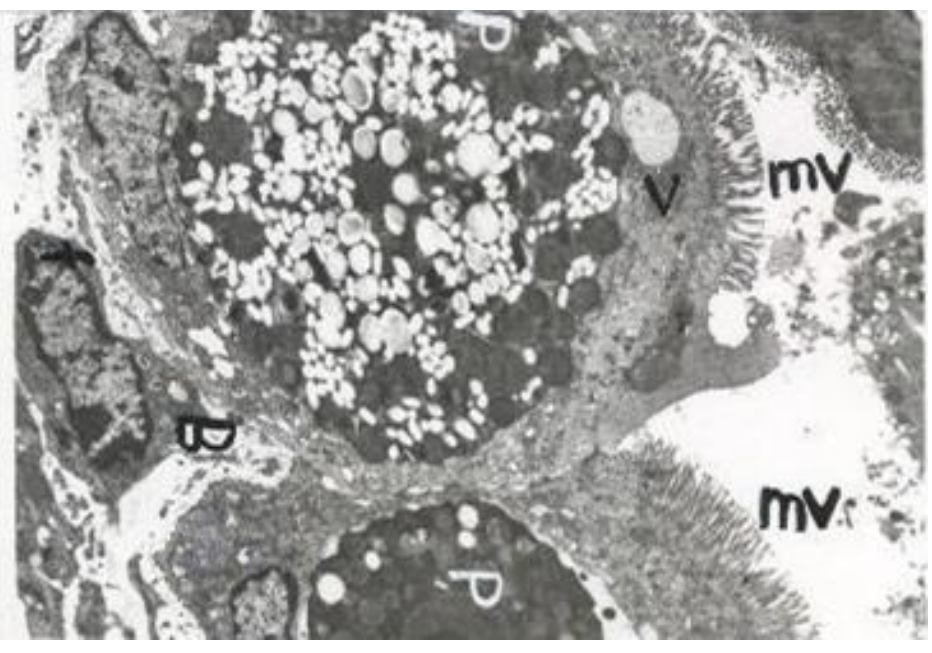

Fig. 8: A micrograph of the proximal small intestine at 30 days old, showing columnar cell with apical microvilli (mv), vacoules (v), nucleus (n) phagosome (p) and lamina propria (B). Uranyl acetate and lead nitrate, X 2. 700. 


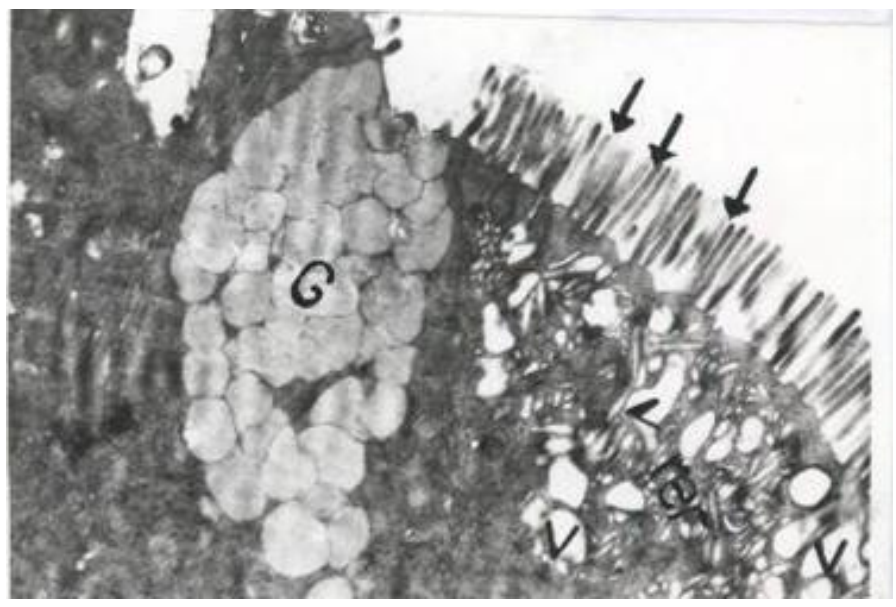

Fig. 9: A micrograph of distal small intestine at 6 days old, showing the absorptive cell with apical microvilli (arrows), dilated cisternae of rough endoplasmic reticulum (rer), vacoules (v), free ribosomes (f), and goblet cell with premucin droplets (G). Uranyl acetate and lead citrate, X 6. 700 .

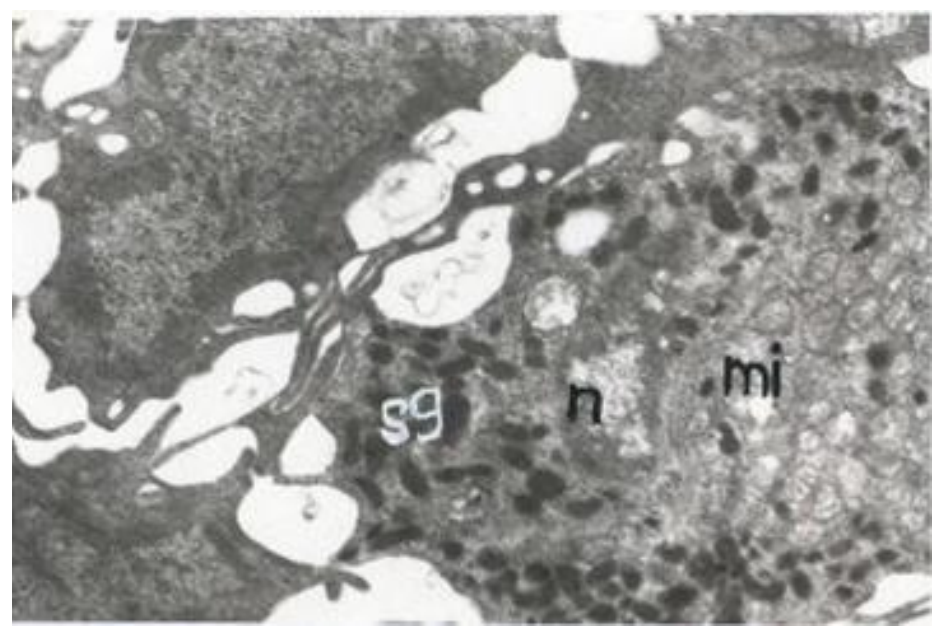

Fig. 10: A micrograph of distal small intestine at 24 days old, showing endocrine cell containing mitochondria (mi), nucleus (n) and polymorphic secretary granules (sg). Uranyl acetate and lead citrate, X 10. 000. 


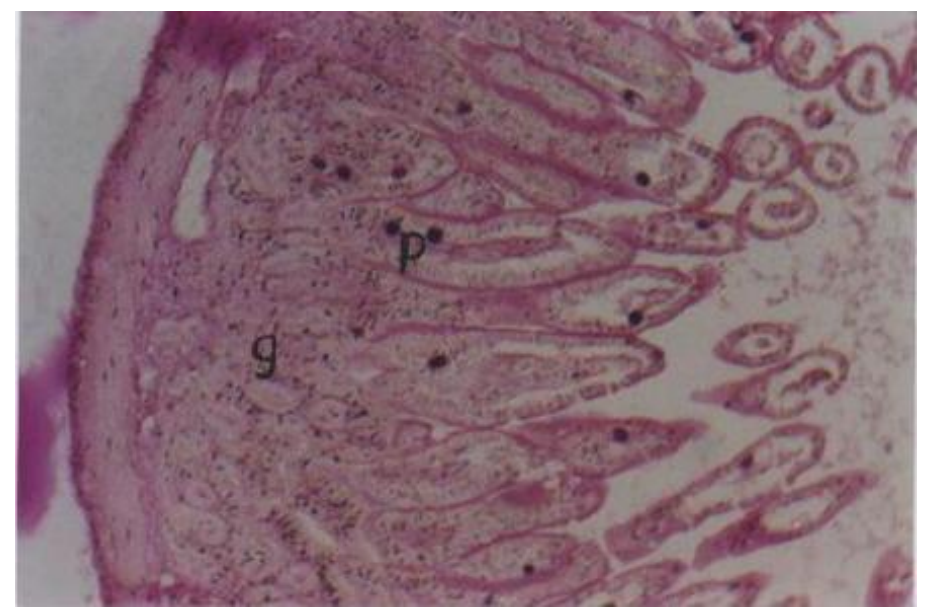

Fig. 11,a: Glycogen particles (g) and phagosomes are clearly visible (p) in the mucosa of the proximal small intestine at 18 days old PAS stain without counter stain, X 10.

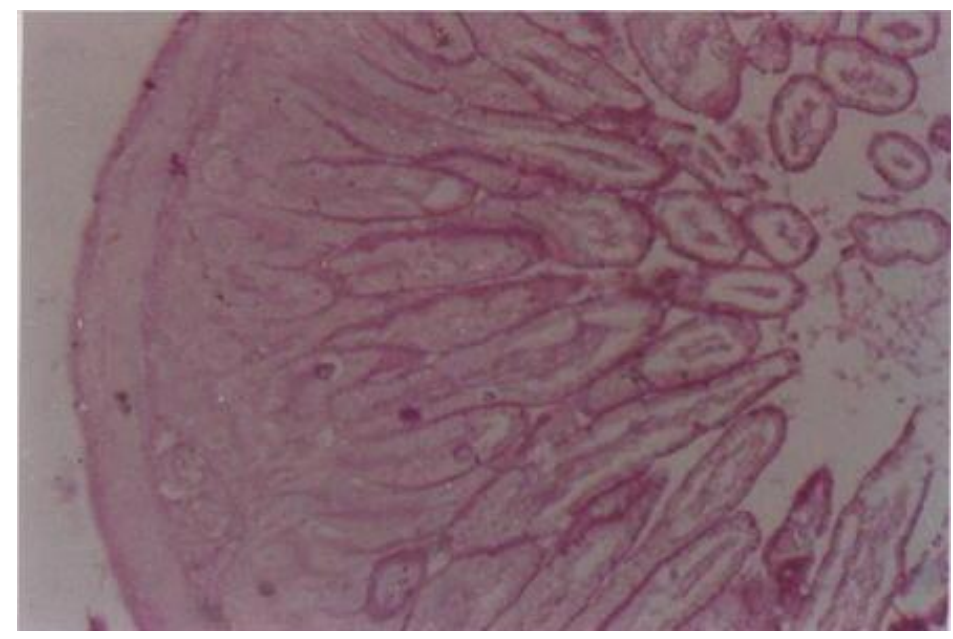

Fig. 11,b: The proximal small intestine at 18 days old showing the positive reaction to PAS stain in the striated border of the surface epithelium of the intestinal villi. PAS stain with diastase, with out counter stain, X 10. 


\section{DISCUSSION}

\section{Light Microscopy}

\section{The proximal and distal small intestine}

In the present study, the surface epithelium of the intestine was simple columnar with a few goblet cells. This was in agreement with the reports given by Aitken (1958) and El-Shamy (1996) in chicken and fowl respectively. Salem (1985) reported that the lamina epithelialis was simple columnar of mucous secreting type in fayoumi fowl. In chicken, the mucosa was composed of finger- like villi (Humphery and Turk, 1974), whereas in growing white leghorn and broiler chickens, the villi were finger- like at 0-day of age and change to a wave-like in the jejunum to tongue- like in the ileum at 30 days of age (Yamauchi and Isshiki, 1991). The present study showed that the villi of the proximal intestine were short and irregular in shape at 0 -day of birth but short and cylindrical in shape at 6,12 and 24 days old and change to short clubshaped villi at 30 days old. These results agree with the report given by $\mathrm{YuB}$ (1997) in the fact that the villi of the small intestine of suckling rabbits at 2 weeks, compared with 4 weeks of age, looked more cylinderical in shape and finger-like in the suckling period, thereafter becoming broader or tongue-like or plate-shaped in mature rabbits. In Turkey, the villi were quite tall and finger-like at 2 days of age and they became compressed and tongue-shaped at 16 days of age (El-Zoghby, 2000). In the present study, the mucosa of the distal small intestinal showed irregular and cylindrical villi at 0-day of birth, and at 6 days old, the villi became wide and cylindrical in shape and at 12 days old, they became long and wide and they become cylindrical at 18 and 24 days old but they became narrow and short at 30 days old. The villi were lined by simple or pseudostratified columnar epithelium at 0-day of birth and simple columnar epithelium at the other age groups. The lamina propria, muscularis mucosa and the core of the villi were similar in structure in all age groups. In the present investigation the intestinal crypts were simple branched tubular invaginations, in all ages. However, in chicken, the crypts were simple tubular gland (Humphery and Turk, 1974). In turkey, the glands became longer, more numerous and closely packed at 16 days of age compared to those of 2 days of age (El-Zoghby, 2000). The glands were simple tubules and slightly coiled in chicken (Aitken, 1958). In the present study, Paneth cells were found but they were absent in the small intestine in chicken (Atiken, 1958). Gastrin cells were occasionally found in the duodenum and jejunum but were 
absent in the proventriculus of the chicken (Larsson, et al., 1974). Ahmed (2002) also found that the ileum of quail contains a few number of argentaffin cells. The present study confirmed the presence of endocrine cells in all age groups in the small intestine. The present information about the length and width of the villi of the proximal and distal small intestines has not previously been reported

\section{Electron Microscopy}

\section{The proximal and distal small intestine}

In the present study, the absorptive columnar cells of the proximal and distal small intestines showed apical striated border due to the presence of microvilli. The core of the microvilli contained bundles of fine collagen fibers extending throughout the length of the villi. Apically, there were tight and intermediate junctions and desmosomes. The lateral cell membranes were characterized by a complexity of interdigitations with adjacent cells. Rough endoplasmic reticulums, ribosomes, Golgi apparatus, mitochondria, vacuoles with different electron density were found. These findings agreed with previous reports in the fowl by Humphrey and Turk (1974) and Michael and Hodges (1973). The presence of apical microvilli in the surface epithelium was also reported by Krause (1972), Staley, et al. (1972) and Bayer, et al. (1975) in opossum, calf and chicken respectively. The presence of mitochondria, vacuoles, smooth endoplasmic reticulum and Golgi apparatus during postnatal development in the opossum is also observed (Krause, 1972). In the present investigation, the pyramidal Paneth cells with apical round secretory granules appeared at 24 days old, in the proximal part of the small intestine. Whereas in the adult rabbit (4 to 6 months) Paneth cells contained spherical granules confined to the apical half of the cells and they were more numerous in the distal parts than the proximal parts (Abdel-Magied and Taha, 1995). In addition, cells with polymorphic secretory granules appeared in all age groups basal to the nucleus and peripherally in the distal parts and sometimes the granules were found around the nucleus so it was difficult to predict whether these cells were endocrine cells and/ or exocrine cells. Moreover, in chick Andrew, et al. (1982) classified the endocrine cells of the gastrointestinal tract into 7 classes; the classification is based on the shape and size of the secretory granules.

\section{Histochemistry}

\section{The proximal and distal small intestine}

In quail, during the post-hatching period, the epithelium of the intestinal villi and the glands reacted positively with PAS stains and the 
reaction increased with advancing age (Ahmed, 2002). The present study confirmed these observations at 6 days old and onward. At 18 and 30 days old, the striated border of the epithelium and goblet cells showed positive reaction to PAS stain. The cytoplasm also contained many fine glycogen particles in all age groups, and numerous phagosomes in younger age groups.

\section{REFERENCES}

Abdel-Magied, E.M. and Taha, A.A.M.A. (1995): Comparison of glandular cell type in the intestinal epithelium of the camel with paneth cells of the rabbit. J. King Saud University. 7: 52-53.

Abdel-Shamy, S. (1996): Histological and histochemical studies of the digestive tract in balady fowl. Ph.D, Thesis, Fact. Vet. Med. Assuit University.

Aherne, W.A. and Dunnil, M.S. (1982): Morphometry. First Edition. Edward Arnold Publishers Ltd. London.

Ahmed, AG.Y. (2002): Histomorphological studies of the gastrointestinal tract of the post hatching Quail. M., Thesis, Fac. Vet. Med. Assuit University.

Aitken, R.N.A. (1958): A histological Study of the stomach and intestine of chicken. J. Anat. 92: 453-466.

Anderw, A. (1976a): Intestinal endocrine cells of chicks around the time of hatching. Cell Tissue Res., 172: 541-551

Bancroft, J.D. and Stevens, A. (1996): Theory and Practice of Histology Techniques. Fourth Edition. Churchil Livingstone, Medical Division of pearson Professional Limited.

Bayer, R.C.; Chawan, C.B.; Bird, F.H. and Musgrave, (1975): Characteristics of the the obsorbtive surface of the small intestine of chicken from 1 day to 14 weeks of age. Poultry Science, 54: 155-169.

Carlson, Bruce M. (1981): Patten's Foundations of Embryology. Forth Edition Ph. D., University of Michigan, Department of Anatomy and Biology Sciences.

Culling, C.F.A. (1973): Handbook of Histology and Histochemical Techinques. Second Edition. London, 88 Kings way W.C.Z.

El-Shamy, S.A. (1996): Histological and Histochemical studies on the digestive tract in fowl. Ph. D. Thesis, Fac. Vet. Med. Assuit University. 
EL-Zoghby, M.A. (2000): Histological studies on the digestive tract of the turkeys at different ages. Ph. D. Thesis, Fact. Vet. Med. Moshtohr. Zagazig University.

Humphery, C.D. and Turk, D.E. (1974): The ultrastructure of normal chick intestinal epithelium. Poultry Science 53: 99-100.

Micheal, E. and Hodges, R.D. (1973): Structure and Histochemistry of normal intestine of fowl. 1- The mature absorptive cell. J. Histochem; 5: 313-333.

Krause, W.J. (1972): Light and Electron Microscopic Studies on the Gastrointestinal Tract of Suckling Echidna (Tachyglossus aculeatus). The Anatomical Record. 172 (4): 603.

Krause, W.J.; Cutts, J.H. and Lesson, C.R. (1977): The Postnatal development of the alimentary canal of the newborn opossum in the -III. small intestine and colon. J. Anat.: 123, 1: 21- 45.

Larsson, L.I.; Sundler, F.; Hakanson, R.; Rehfeld, T.F. and Stadil, F. (1974): Distribution and properties of gastrin cells in the gastrointestinal tract of chicken. Cell tissue Res., 154: 409-422.

Salem, H.F. (1985): Histological and Histochemical studies on stomach and intestine of fayoumi fowl with special reference to age and ration variations $\mathrm{Ph}$. D, Thesis. Fac. Vet. Med. Zagazig University. Department of Anat. and Histology.

Staley, T.E.; Corley, L.D.; Bush, L.J. and Jones, E.W. (1972): The Ultrastructure of Neonatal Calf Intestine and Absorption of Heterologous Protiens. Anat. Rec. 172: 559-580.

Sandford, J.C. (1996): The domestic rabbit. The British Rabbit council. Fifth edition.

Thienpont, D.; Rochette, F. and Vanparijs, O.F.J. (1986): Diagnosing Helminthiasis By Corprological Examination. Second Edition. Beers, Belgium.

Yamauchi, K. and Isshik, Y. (1991): Scanning electron microscopic observation on the intestinal villi in growing white leghorn and broiler chickens from 1 to 30 days of age. Br. Poult. Sci.: 32 (1): 67-78. Department of Anat. and Histology.

$Y u B$ WS., C. (1997): The morphological changes of intestinal mucosa in growing rabbits. Lab. Anim. Jul., 31 (3): 254-63. 